\title{
Samtal II: Samtal om sinnen, lek och kreativitet i skapande processer
}

Eva Borseman, Cecilia Hofsten, Mimmi Larsson, Elis Storesund, Martin Wikmark

MW Ja, vi ställer ju krav på dem. Vid något tillfälle lyssnar vi bara på hur det låter. Dom får blunda - eller BÖR blunda. Och andra gången får vi se. Det kan ha med riktning att göra också, en del har ordnat så. Dom står på ett visst sätt. Och hon börjar och sedan kommer den, sen kör allihop och då kommer det förmodligen, jo den slutade. I början uppfattade de det inte alls då det bara är öronen.

$\mathrm{CH}$ Det är en spännande tanke att man genom att stänga av ett sinne, kan förstärka ett annat, så att man till exempel genom att blunda kan utveckla sitt lyssnande. Men samtidigt tycker jag att synen kan förstärka upplevelsen av en konsert. Det är stor skillnad mellan att sitta hemma och lyssna till inspelad musik och att erfara levande musik tillsammans med andra. Att vara i ett rum där man kan se hur musikerna relaterar till varandra, kanske svettas och verkligen jobbar med sina instrument - det fördjupar helhetsupplevelsen. - Jag blir lite nyfiken när du säger att de ska gå ut och spela någonting. Hur då?

MW Ni har tio minuter på er sedan ska ni komma tillbaka och framföra något världen aldrig hört förut. Instrumenten har studenterna i ett tidigare moment valt helt individuellt, utan att veta var det hela ska hamna till slut. Jag har liksom totat ihop studenterna fyra och fyra. Först var dom helt ensamma, sedan blir dom två och två, tre och tre, fyra och fyra beroende på hur många det är i en grupp. Då brukar de bara rycka tag i någon för att bilda nya konstellationer.

Hur du refererar till det här kapitlet:

Borseman, E., Hofsten, C., Larsson, M., Storesund, E. and Wikmark, M. 2018. Samtal II: Samtal om sinnen, lek och kreativitet i skapande processer. I: von Schantz, U., Thorgersen, K. and Lidén, A. (red.) De estetiska ämnenas didaktik Utmaningar, processer och protester. Pp. I25-I 29. Stockholm: Stockholm University Press. DOI: https://doi.org/IO.I6993/bap.h. License: CC-BY 
Ibland har det blivit tre maracas och ett skakrör eller något sånt. Och så har jag sagt: "Ni får inte byta instrument, nu har ni det här...”

$\mathrm{CH}$ De kommer inte in då och sjunger Bä bä vita lamm och skakar till den?

MW Nej det brukar inte vara det och ibland säger jag det är enbart instrumenten. Många lägger en sång $\mathrm{i}$ bakgrunden för att få en struktur på det hela och så säger de förtjusta: "Kan ni gissa vilken sång det var?" - Nääää, de kan inte det, de som vet tycker det är jättelätt vilken det ska vara. De får ta vissa förutsättningar.

$\mathrm{CH}$ Jag har gjort så att varje grupp får välja ett instrument. Jag vill att de ska uppfatta någon karaktär från sitt instrument; sitt instruments väsen... och sedan hitta på en lek utifrån det ljudet. Ofta finner de på fantasifulla lösningar när de arbetar i sina mindre grupper. Det är förbryllande och tankeväckande att de kan göra det när många studenter samtidigt är så extremt rädda och blyga inför varandra. Ofta brukar jag testa övningarna de har hittat på i mina barngrupper på Kulturskolan.

$\mathrm{CH}$ Ja det är roligt för mig också. En gång till exempel, hade en grupp valt kastanjetter som sitt instrument. När de spelade associerade de till tänder som skallrade och vidare till farliga hajar i världshaven. De byggde upp en ö av stolar i mitten av rummet och så simmade vi andra runt den där ön. När vi hörde en kastanjett så förstod vi att hajarna närmade sig och att det gällde att se upp. Vi fortsatte simma med stor uppmärksamhet på ljudet. När sedan båda kastanjetterna spelade var det fara å färde och alla måste hjälpas åt att kvickt komma upp på stolarna. Man är räddad först när alla är uppe. Nästa gång tar man bort en stol så ön blir mindre och mindre. -

Det blev en klassisk samarbetsövning där alla måste hjälpa alla. Till slut är det bara en stol kvar och så är det kanske tio barn som ska komma upp på den enda stolen. Jag testade leken i en barngrupp i går. Jag trodde att de kanske var trötta på sådana här sociala lekar som vi vuxna är så förtjusta i..., men dom tyckte det var vansinnigt roligt! Vi hade jättekul! 
ES Det här är också hur man kopplar olika uttryck till varandra. Här kopplar du drama till musik. Någon gång har jag fått frågan från en kollega -Gör du den här dramaövningen i dansen? För man kan ju använda samma övningar fast man har olika innebörd eller syften med det.

EB Det tror jag är jätteroligt för studenterna när det blir igenkänning på ett sätt och sedan en vidareutveckling. Det blir lite det vi pratat om.

ES Men det är också att vi både använder barnkulturen/leken och det konstnärliga. Hur man jobbar konstnärligt i ett uttryck.

ML Skulle du inte kunna utveckla det och berätta om hur du använder det?

EB När jag råkade hitta skissen uppe vid kopiatorn och skulle gå på lektion och förstod att den kom från dansen, om Laban. [Rudolf Laban (I879-I958) koreograf, dansare och skapare av ett notationssystem för dans]. Där jag tog kroppsuppfattning och rumsuppfattning och kvaliteter och relationer som fyra övergripande begrepp som fanns i din skiss Elis och satte upp på tavlan de här begreppen. Så märkte jag att de hade de här begreppen klara för sig och kunde titta på den bildsaga som de gestaltade utifrån dans-Laban begrepp och det tyckte jag blev jättespännande för mig hur det gick igenom och likaså från bilden att de använde sig av de gestaltningar de hade gjort i bilden utifrån deras teman och förde in dem i dramatiseringen. Det var väl där...

$\mathrm{CH}$... vi pratade om att vi skulle använda vissa begrepp som är gemensamma för oss. Att det skulle kunna vara meningsfullt för oss att poängtera dem. Exempelvis tempo, dynamik, kraft, riktning, rum, tid, paus...

ES Studenterna får förhålla sig till begrepp när de gör en process i dansen. Från att man är själv och utvecklar rörelser till att man blir en grupp. Begreppen återkommer, precis som när du Mimmi sa det här med likheten när de använder skraporna. Samma process händer hos dig som hos mig, Mimmi. Jag tänker speciellt på en sak jag brukar göra, när två par visar sina spegelkoreografier, och så lägger man på 
mänskliga skuggor. Det händer olika saker i rummet på olika nivåer och på olika sätt. Det blir så synligt. Det blir ju som en bild också för dem som är åskådare, en rörlig bild. Så när du säger att ni i bild sitter och tittar på målningar och säger Wow nu får den här ny riktning, så är det ju precis samma sak när studenterna sitter som åskådare i dansen. Wow, det är jättebra! Vad är det som är bra”, frågar jag då. Så får studenterna sätta ord på vad de har sett, precis som du säger att ni sätter ord på bilden.

CH Jag brukar använda de här utgångspunkterna för att få syn på hur man kan variera ett känt material. --- Istället för att oreflekterat föra traditioner vidare i all oändlighet eller för den delen revoltera och slänga ut de traditionella ramsorna och sångerna (till exempel Alice Tegnérs), så kan man förhålla sig vaket och fritt till detta material. Jag tycker själv att det är någonting vackert och fascinerande med sånger som likt stafettpinnar förs över från generation till generation, men naturligtvis kan det också bli rutinmässigt och stendött. Jag vill att studenterna ska uppmärksamma sitt eget musicerande och inte bara texterna. Vad händer om man sjunger snabbt? Om man sjunger svagt? Ljust? Mörkt? Vad händer om man leker med artikulationen? Hur förvandlas sången om man sänker ner den i en känsla av vemod? Eller tuffhet? De får i uppgift att i sin grupp, tolka en känd ramsa. Ibland har alla grupper fått samma ramsa bara för att få uppleva hur otroligt många olika tolkningar man kan göra av ett och samma material. Det blir ofta väldigt humoristisk. De kanske börjar långsamt och så blir det snabbare och snabbare och till slut är det så fort så det blir ja... eller så viskar man sin ramsa och så mitt $\mathrm{i}$ - så skriker man! Jag brukar koppla till TV-programmet Så mycket bättre, men också till att lagtexter måste tolkas och att olika församlingar väljer att tolka Bibeln på olika sätt.

ES Jag tycker det är spännande det du säger för jag tänker väldigt mycket på att om man ska utforska och gå djupt in i någonting, är det detsamma som att upptäcka variationer och nyanser. Någonting som är utvecklingsbart är ju toner och nyanser, och för det måste man skapa nära relation till 
det man håller på med. Jag tänker också vad jag vill att studenterna ska ha med sig. Om de bara ser dansen som olika slags övningar, som t ex "kom alla barn", och så upprepar de rörelseleken på samma sätt. Då tröttnar ju barnen och så gör man inte den leken något mer. Då är det så viktigt att vi jobbar med variationer och nyanser. Det ska inte bli små modeller som studenterna får med sig, utan om hur kan man skapa en relation till någonting och utveckla det?

EB Det där tycker jag stämmer jätteväl med drama också. Att ha en utgångspunkt men att hela tiden kunna vidga och se.

$\mathrm{CH}$ Och många gånger kan det vara så som jag tror Ingela säger i sin introduktionsföreläsning att genom att upprepa någonting kan variationer skapas. Genom att hålla på länge... Man behöver inte tänka att genom att lämna så kommer det nytt. Genom att vara kvar kan vi också förnya! 
